\title{
Rheology of spreadable goat cheese made with autochthonous lactic cultures differing in their ability to produce exopolysaccharides
}

Frau Silvia FLORENCIA ${ }^{1}$

\begin{abstract}
The aim of this study was to compare the rheology of spreadable cheeses elaborated with autochthonous lactic starter cultures without the addition of exopolysaccharide-producing strain in the same starter with exopolysaccharide-producing strain. From a rheological standpoint, both samples were characterized as weak viscoelastic gels and pseudoplastic products. It was concluded that cheese made with exopolysaccharide-producing strain showed smaller G', G”, and $\eta^{\star}$ values over the range of frequencies studied and smaller critic stress values than the cheese without exopolysaccharide-producing strain. The results obtained indicate that cheeses without exopolysaccharide-producing strain need to be added with any texture enhancer product.

Keywords: rheology; spreadable cheese; exopolysaccharide.
\end{abstract}

\section{Introduction}

Some lactic acid bacteria (LAB) are able to synthesize extracellular polysaccharides also called exopolysaccharides (EPS). They are long-chain and high molecular weight polymers able to dissolve or disperse in water and enhance fermented product texture and viscosity. Lactic acid bacteria (LAB) that produce EPS play an important role in the dairy industry because of their contribution to the consistency and rheology of fermented milk products. The EPS polymers can be considered as natural biothickeners because they are produced in situ by the LAB-starters that have General Recognised As Safe (GRAS) status (BANIK; KANARI; UPADHYAY, 2000; BROADBENT et al., 2001; DE VUYST et al., 2001; DUBOC; MOLLET, 2001; RUAS-MADIEDO; HUGENHOLTZ; ZOON, 2002; ASLIM; YÜKSEKDAG; BEYATLI, 2005; SÁNCHEZ MARTÍNEZ, 2005). Therefore, the EPS produced also have economic importance (WELMAN; MADDOX, 2003; SOYDEMIR, 2008). The EPS produced by LAB have been used in several dairy products. Most of the studies have been conducted on yogurt in which significant advantages such as increased viscosity or lowered syneresis have been gained (WACHER-RODARTE et al., 1993; JIMÉNEZ-GUZMÁN et al., 2009). These characteristics might also be used in the production of other dairy products such as spreadable cheeses, on which only few studies have been made (JIMÉNEZ-GUZMÁN et al., 2009). The EPS have extensively been used as gels, emulsifiers, and stabilizing agents.

Very limited information on the application of EPSproducing cultures in spreadable cheeses is available.

Spreadable cheeses are obtained by acid or mixed coagulation and characterized as slightly acid soft homogeneous products that are white in color and smooth-textured to palate (GUINEE; PUDJA; FARKYE, 1999). The rheological properties of these products play a determining role in the consumer acceptance (FRAU, 2011); this variety of cheese would greatly benefit from EPS producing strains because of the acidification method used in its manufacture allows sufficient time for the culture to grow and produce EPS and its high moisture content. Hassan (2008) showed that EPS formed large masses of a dense filamentous structure in acid-coagulated cheese. Such masses, although forming separate entities, seem to be interacting with the protein network. The presence of the EPS within the structure reduces protein-protein interactions and cheese rigidity (HASSAN, 2008).

Rheology allows knowing both cheeses texture and body, features that are affected by the parameters involved in their processing and the addition of EPS producing-strain. Viscoelastic properties of cheeses are related to their quality and acceptability (HASSAN et al., 2004).

Rheological characterization of Argentinean cheeses will allow the introduction of a new concept not used so far and promote work within an area tightly closed to the sensory analysis (CASTAÑEDA, 2002).

The aim of this study was to compare the rheology of spreadable cheeses elaborated with autochthonous lactic starter cultures without the addition of EPS producing strain (EPS $\left.{ }^{-}\right)$in the same starter with EPS- producing strain (EPS ${ }^{+}$.

\section{Materials and methods}

\subsection{Starter culture}

The strains used in this study were isolated in the Laboratory of Centro de Referencia para Lactobacilos (CERELA, Tucumán, Argentina) from goat cheeses elaborated in Santiago del Estero. The criteria for selecting these strains are explained in Frau (2011). The autochthonous starter culture combinations used in this study are listed in Table 1.

${ }^{1}$ Consejo Nacional de Investigaciones Científicas y Técnicas - CONICET, Universidad Nacional de Santiago del Estero - UNSE, Avda Belgrano (S) 1912, CP 4200, Santiago del Estero, República Argentina, e-mail:ffrau@unse.edu.ar

${ }^{*}$ Corresponding author 


\subsection{Cheese manufacture}

Two vats of cheese (three liters each) were made on one day from fresh goat milk obtained from a local farm. For each trial, six litters of milk were pasteurized at $75^{\circ} \mathrm{C}$ for 30 minutes, then cooled to $37^{\circ} \mathrm{C}$, and $0.035 \mathrm{~g} / \mathrm{L}$ of $\mathrm{CaCl}_{2}$ were added. After that, the milk was divided into two batches (three liters each). One of the batches was inoculated with EPS, and the other one with $\mathrm{EPS}^{+}$starter culture (Table 1); both batches were inoculated at $1 \%$. The inoculated milks were incubated at $37^{\circ} \mathrm{C}$ until $\mathrm{pH}<6$, when the bovine curdle was added ( $20 \%$ of the amount needed for enzymatic coagulation) and incubated at $37^{\circ} \mathrm{C}$ for 1 hour. Next, the cheese curds were first salted (1.5\% of the milk weight) and then placed in cheesecloth at $30^{\circ} \mathrm{C}$ until $\mathrm{pH}<4.5$ facilitating syneresis of the curd. The cheese obtained in this way was packed in polyethylene bags and matured at $7{ }^{\circ} \mathrm{C}$ for 5 days. Samples from each cheese were taken on day zero and 7 days after manufacture for rheological studies. The values reported are the means of the 6 cheese making trials (FRAU, 2011).

\subsection{Experimental design}

Each experimental block consisted of two cheeses made from the same batch of goat milk and fermented with two combinations (Table 1). This block structure was replicated three times.

\subsection{Rheological measurements}

The rheological characteristics of the experimental spreadable cheese were obtained using an AR 1000 rheometer (TA Instuments, Leatherhead, Surrey, UK). A $25 \mathrm{~mm}$ stainless steel parallel plate geometry with gap size of $1 \mathrm{~mm}$ was used. All experiments were performed at a constant temperature of $25^{\circ} \mathrm{C}$ using a Peltier plate to control temperature. The samples were carefully placed on the plate using a plastic spoon (KELLY; DONNEL, 1998).

Table 1. Culture combinations used as starters (FRAU, 2011).

\begin{tabular}{|c|c|c|c|}
\hline $\begin{array}{c}\text { Culture } \\
\text { combination }\end{array}$ & $\begin{array}{c}\text { Culture } \\
\text { components }\end{array}$ & $\begin{array}{c}\text { Description of } \\
\text { culture component }\end{array}$ & Proportions \\
\hline \multirow[t]{3}{*}{ EPS- $^{-}$} & CRL 1799 & $\begin{array}{l}\text { Fast acid-producing strain } \\
\text { Lactobacillus fermentum }\end{array}$ & $1: 1: 1$ \\
\hline & CRL 1803 & $\begin{array}{l}\text { Proteolytic strain } \\
\text { Lactobacillus fermentum }\end{array}$ & \\
\hline & CRL 1785 & $\begin{array}{l}\text { Aroma compounds- } \\
\text { producing strain } \\
\text { Enterococcus faecium }\end{array}$ & \\
\hline \multirow[t]{4}{*}{$\mathrm{EPS}^{+}$} & CRL 1799 & $\begin{array}{l}\text { Fast acid-producing strain } \\
\text { Lactobacillus fermentum }\end{array}$ & $1: 1: 1: 3$ \\
\hline & CRL 1803 & $\begin{array}{l}\text { Proteolytic strain. } \\
\text { Lactobacillus fermentum }\end{array}$ & \\
\hline & CRL 1785 & $\begin{array}{l}\text { Aroma compounds- } \\
\text { producing strain } \\
\text { Enterococcus faecium }\end{array}$ & \\
\hline & CRL 1808 & $\begin{array}{l}\text { EPS-producing strain } \\
\text { Lactobacillus rhamnosus }\end{array}$ & \\
\hline
\end{tabular}

EPS $^{+}$: starter containing exopolysaccharide-producing bacterial strain; EPS ${ }^{-}$: starter without exopolysaccharide-producing bacterial strain.
All the samples were studied and the linear viscoelastic region was determined by stress sweep measurements. In order to create a rheogram describing the structure of each sample, a frequency sweep was carried out (KEALY, 2006; HASSAN et al., 2003). From the stress sweep, the value for the critical stress was found, and it was determined whether it corresponds to the fluency threshold (BENNA-ZAYANI et al., 2008; SAN MARTÍN et al., 2007). The linear viscoelastic region was determined by stress sweep measurements. The stress was linearly increased from 1 to $5.000 \mathrm{~Pa}$ at a frequency of $1 \mathrm{~Hz}$. During the time of the experiment, 1 data point was collected per second.

Dynamical rheological measurements (frequency sweep) were used to determine the elastic or storage module $\left(G^{\prime}\right)$, viscous or loss module $\left(G^{\prime \prime}\right)$, and complex viscosity $\left(\eta^{*}\right)$ of the cheeses elaborated in terms of frequency $(\omega)$; the parameters used were $1-100 \mathrm{~Hz}$ set at $1.5 \mathrm{~Pa}$. These parameters enable the rheological characterization of viscoelastic materials such as the spreadable cheeses under study.

For each batch produced, three separate samples were tested and the average was calculated.

\subsection{Statistical analysis}

Data were processed using the rheometer own software. Analysis of variance (ANOVA) was carried out using STATISTICA software (version 6.0), in which the effect of culture combination and replicates were estimated for all response variables. The Tukey's test was used to determine whether the averages of two sets of measurements were significantly different at $\mathrm{P}<0.05$.

\section{Results and discussion}

\subsection{Stress sweep}

The stress sweep carried out on the EPS ${ }^{-}$and EPS ${ }^{+}$samples indicates that both have a critical stress value: EPS, 3630.7 Pa; EPS $^{+}, 1363.1 \mathrm{~Pa}$. It can be seen that the EPS- ${ }^{-}$cheese shows a higher critical value for the stress than that of the $\mathrm{EPS}^{+}$cheese. The decrease in the value of the critical stress for the EPS ${ }^{+}$sample can be explained by the decrease in the number of interactions between the protein aggregates due to the presence of EPS in the continuous phase surrounding them.

The critical value of stress $\left(\tau_{c}\right)$ indicates a transition between the linear regime and non-linear regime. Depending on the material, $\tau_{c}$ can be taken as the yield stress value; this can be done if the viscoelastic analysis shows a maximum of G” (LARIBI et al., 2005; BENNA-ZAYANI et al., 2008). The viscous modulus (G") did not reach its maximum for either sample (EPS ${ }^{-}$and EPS $^{+}$chesses); Figure 1 shows the curves obtained for each cheese. The results show that the spreadable cheeses did not have yield stress even if the strain-stress curves show a critical stress. The latter could be attributed to the end of the linear regime or to a drastic change in the rheological behaviour but not to the presence of a threshold (BENNAZAYANI et al., 2008). 
Applying a small stress ( $<<$ critical stress) on the gel causes a reversible stretching of the threads making up the cheese matrix. However, if the stress applied is higher than the critical stress, the threads break.

\section{Frequency sweep}

Figures 2 and 3 show that both EPS- ${ }^{-}$and $\mathrm{EPS}^{+}$cheeses exhibited characteristics typical of a weak viscoelastic gel, with G' greater than G", and both showed some frequency dependence. G' and G" showed similar frequency dependence, but the moduli of cheese made with EPS- showed more frequency dependence [higher slope of $\log \left(G^{\prime}\right)$ and $\log \left(G^{\prime \prime}\right)$ vs. $\log$ (frequency)] than that of the $\mathrm{EPS}^{+}$cheese (Table 2). In both types of samples analysed the elastic component contributes than the viscous module to viscoelasticity more ( $\left.G^{\prime}>G^{\prime \prime}\right)$ which leads to a structure resembling a solid within the range of frequencies studied, which was also observed by other authors (MESSENS et al., 2002; SAN MARTÍN et al., 2007).

The rise of G' with $\omega$ might be due to casein particles fusion as a consequence of the rearrangement of inter- and intra-molecular forces, which in turn results in an increased contacting surface between the casein aggregates, and

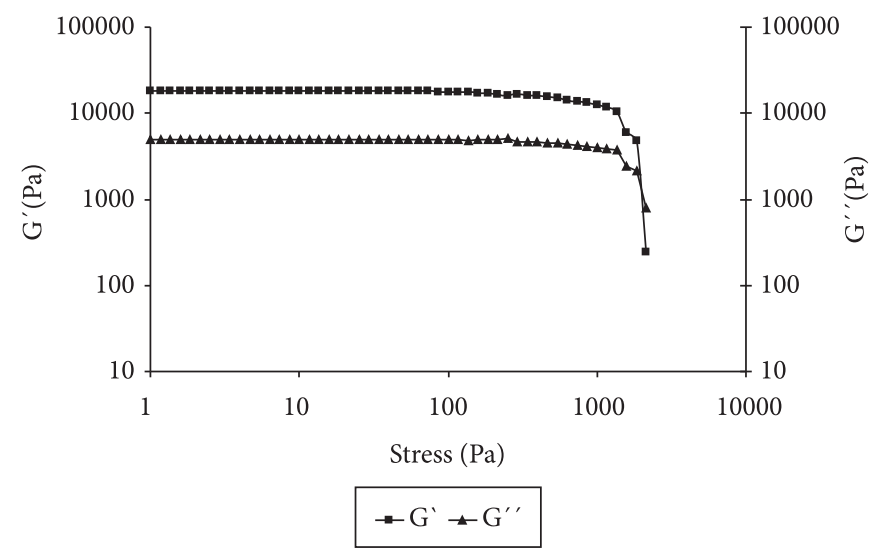

Figure 1. G' and G" variation with stress EPS ${ }^{-}$and EPS $^{+}$cheeses. G': elastic modulus; G": viscous modulus; EPS $^{+}$: starter containing exopolysaccharide-producing bacterial strain; EPS ${ }^{-}$: starter without exopolysaccharide-producing bacterial strain. possibly to the additional particles added to the web (ROEFS; DE GROOT-MOSTERT; VAN VLIET, 2000; HERNÁNDEZTINOCO et al., 2004).

The interesting data obtained through this type of dynamic (or oscillatory) measurements are the contributions to the internal structure of the sample from the elastic and viscous module, $\mathrm{G}^{\prime}$ and $\mathrm{G}$ " $(\mathrm{Pa})$, respectively, and the complex viscosity, $\eta^{*}$ (Pa s) (KEALY, 2006).

EPS $^{+}$cheese show smaller values of G' and G' than EPSthroughout the entire range of frequencies under study (i.e. $1-100 \mathrm{~Hz}$ ); which was also noted by which is also observed by Hassan et al. (2003).

In order to compare G' and G', it was necessary to choose a data point at a single frequency because these values are functions of the frequency of oscillation; the following values $1,50.26$, and $99 \mathrm{~s}^{-1}$ were arbitrarily chosen for comparison. Full data are shown in Figures 2 and 3. It was determined that there are significant differences $(\mathrm{p}<0.01)$ between the EPS ${ }^{-}$and EPS $^{+}$cheeses. The values for G'and G' obtained are included in Table 2.

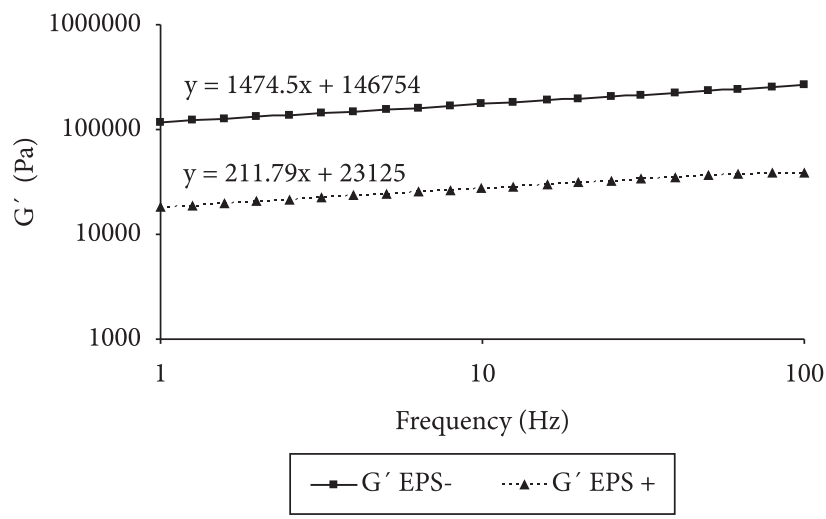

Figure 2. G' variation with $\omega$ in $\mathrm{EPS}^{-}$and $\mathrm{EPS}^{+}$cheeses. G': elastic modulus; G": viscous modulus; EPS $^{+}$: starter containing exopolysaccharide-producing bacterial strain; EPS": starter without exopolysaccharide-producing bacterial strain.

Table 2. Viscoelastic parameters of cheese made with different culture combinations.

\begin{tabular}{lccc}
\multicolumn{1}{c}{ Parameter } & Significance & \multicolumn{2}{c}{ Culture combination } \\
\cline { 3 - 4 } & & EPS $^{-}$ & EPS $^{+}$ \\
\hline Elastic modulus, G' at $1 \mathrm{~Hz}(\mathrm{~Pa})$ & $\mathrm{P}<0.01$ & 117400 & 18005 \\
Elastic modulus, G' at $50.26 \mathrm{~Hz}(\mathrm{~Pa})$ & $\mathrm{P}<0.01$ & 232750 & 36050 \\
Elastic modulus, G' at $99 \mathrm{~Hz}(\mathrm{~Pa})$ & $\mathrm{P}<0.01$ & 265200 & 38745 \\
Viscous modulus, G' at $1 \mathrm{~Hz}(\mathrm{~Pa})$ & $\mathrm{P}<0.01$ & 32400 & 5272 \\
Viscous modulus, G' at $50.26 \mathrm{~Hz}(\mathrm{~Pa})$ & $\mathrm{P}<0.01$ & 69255 & 10764 \\
Viscous modulus, G' at $99 \mathrm{~Hz}(\mathrm{~Pa})$ & $\mathrm{P}<0.01$ & 83895 & 12760 \\
Slope of $\log \left(\mathrm{G}^{\prime}\right)$ vs. $\log$ frequency & $\mathrm{P}<0.01$ & 1474.5 & 211.79 \\
Slope of $\log \left(\mathrm{G}^{\prime \prime}\right)$ vs. $\log$ frequency & $\mathrm{P}<0.01$ & 512.91 & 75.9 \\
\hline
\end{tabular}

EPS $^{+}$starter containing exopolysaccharide-producing bacterial strain; EPS-: starter without exopolysaccharide-producing bacterial strain; G”: viscous modulus. 
The elastic modulus ( $\left.G^{\prime}\right)$ dominates the at-rest response of the samples implying that at the frequencies tested, the sample behaves as a solid (Figure 2 and 3 ).

Figure 4 shows a typical pseudoplastic profile (KEALY, 2006) for both EPS ${ }^{-}$and EPS ${ }^{+}$cheeses. It is expected that the complex viscosity $\eta^{\star}$ relates somehow to the cohesiveness of the sample (estimating deformation before the structure breakdown) (KEALY, 2006).

Clearly, measurements in the linear viscoelastic region involve probing the structure of the sample in a non-destructive manner, but an irreversible deformation takes place in the mouth. However, it is likely that these quantities can indicate the initial experience of a consumer (KEALY, 2006).

The rheological results agree with the macroscopically appearance of experimental cheeses (Figure 5 and 6). EPSsamples showed little pleasant structure, and not as much unctuosity as expected from a spreadable cheese, unlike the $\mathrm{EPS}^{+}$cheese samples. When stirring the cheeses, it was observed that $\mathrm{EPS}^{+}$samples quickly and easily became homogeneous (Figure 6), whereas the samples made using EPS ${ }^{-}$after identical stirring exhibited syneresis, which led to a macroscopically granular appearance (Figure 5). A likely reason why EPS ${ }^{+}$ samples broke down more easily than EPS ${ }^{-}$samples is that there are fewer protein-protein interactions at the critical sites (where the strands are thinnest) to overcome in the network (HASSAN et al., 2003). These results would point out that EPS $^{-}$cheese needs to be added with an additive enhancing their textural attributes.

The decrease of the critical stress in the EPS ${ }^{+}$samples can be explained by the decreased possibility of interactions between the protein aggregates due to the presence of EPS in the continuous phase surrounding the aggregates. This most probably also contributed to the lower values of G' and G' in the EPS ${ }^{+}$chesses as compared to EPS ${ }^{-}$cheeses (Table 2), which was also observed by Skriver (1995). Lucey et al. (1997, 1998) and Hassan et al. (2003), and suggests that an extensive particle

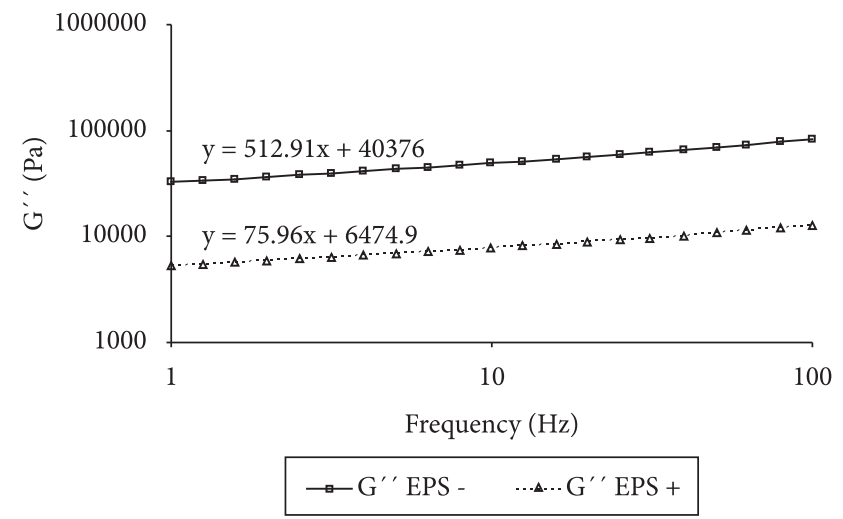

Figure 3. G" variation with $\omega$ in $\mathrm{EPS}^{-}$and $\mathrm{EPS}^{+}$cheeses. $\mathrm{EPS}^{+}$: starter containing exopolysaccharide-producing bacterial strain; EPS-: starter without exopolysaccharide-producing bacterial strain. rearrangement during structure formation results in dense clusters of aggregates and lower G'values (HASSAN et al., 2003).

The difference in the protein network structure between EPS $^{-}$and EPS $^{+}$samples will contribute to differences in flow behaviour. The presence of EPS reduced G" relatively more than G' (Figure 2 and 3), and therefore, $\mathrm{EPS}^{+}$curd cheeses appeared more elastic in nature than EPS-.

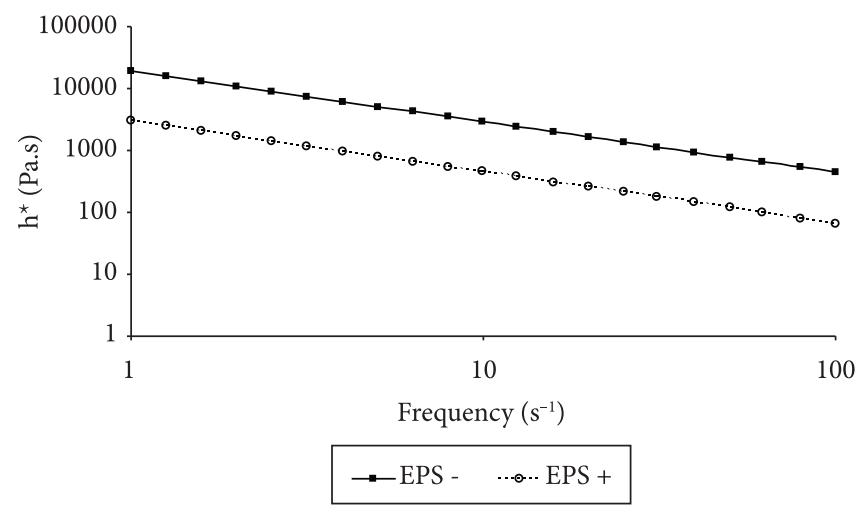

Figure 4. Complex viscosity $\left(\eta^{*}\right)$ in EPS- and EPS ${ }^{+}$cheeses. EPS ${ }^{+}$: starter containing exopolysaccharide-producing bacterial strain; EPS-: starter without exopolysaccharide-producing bacterial strain; $\eta^{*}$ : complex viscosity.

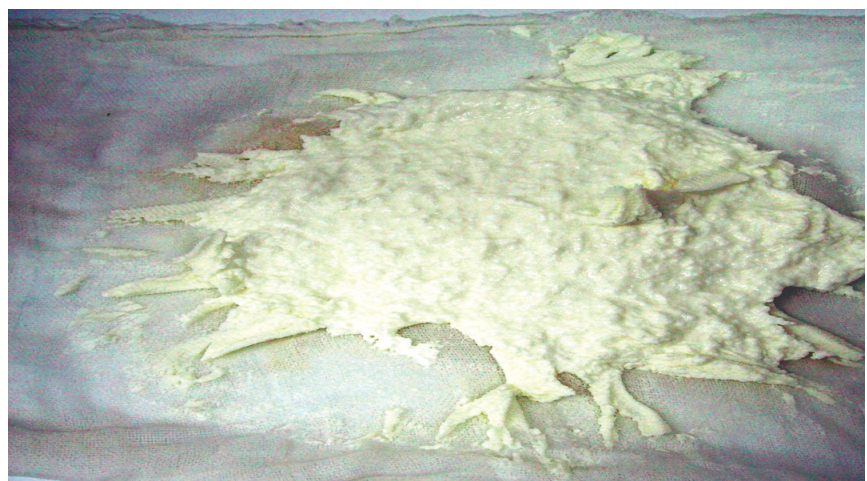

Figure 5. Spreadable cheese made with $\mathrm{EPS}^{-}$culture. Macroscopically appearance.

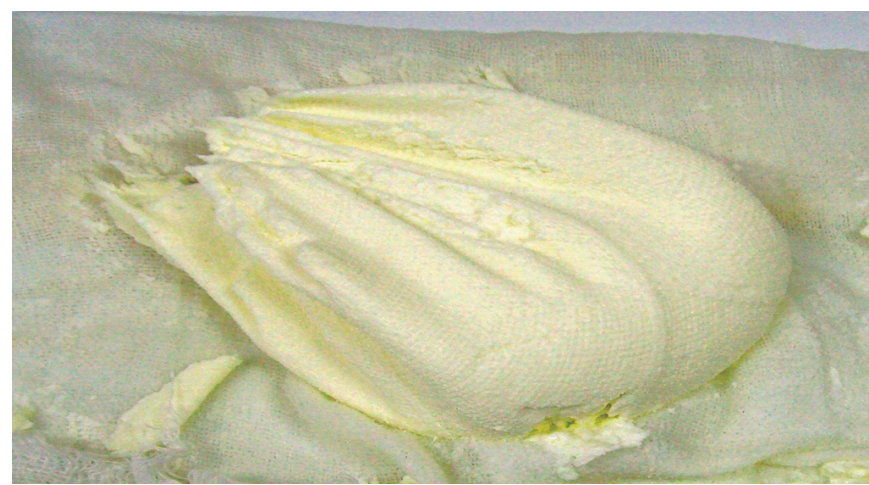

Figure 6. Spreadable cheese made with $\mathrm{EPS}^{+}$culture. Macroscopically appearance. 


\section{Conclusion}

Both EPS ${ }^{-}$and EPS $^{+}$cheeses exhibited features of a weak viscoelastic gel although significant differences can be observed between the rheological parameters G' and G" of the samples.

Both samples were characterized as pseudoplastic products.

It was observed that including EPS producing-strain to the starter cultures of spreadable goat cheeses affects positively their rheology since an enhanced texture was achieved without using gums or stabilizers.

The rheological characterization of spreadable goat cheeses embodies an innovating tool for cheese standardization.

\section{References}

ASLIM, B.; YÜKSEKDAG, Z. N.; BEYATLI, Y. Exopolysaccharide production by Lactobacillus delbrueckii ssp. bulgaricus and Streptococcus thermophilus strains under different growth conditions. World Journal of Microbiology \& Biotechnology, v. 21, p. 673-677, 2005. http://dx.doi.org/10.1007/s11274-004-3613-2

BANIK, R. M.; KANARI, B.; UPADHYAY, S. N. Exopolysaccharide of the gellan family: prospects and potential. World Journal Microbiology \& Biotechnology, v. 16, p. 407-414, 2000. http:// dx.doi.org/10.1023/A:1008951706621

BENNA-ZAYANI, M. et al. Stabilisation of W/O/W double emulsion by polysaccharides as weak gels. Colloids and Surfaces A: Physicochemical and Engineering Aspects, v. 316, p. 46-54, 2008. http://dx.doi.org/10.1016/j.colsurfa.2007.08.019

BROADBENT, J. R. et al. Use of exopolysaccharide-producing cultures to improve the functionality of low fat cheese. International Dairy Journal, v. 11, p. 433-439, 2001. http://dx.doi.org/10.1016/S09586946(01)00084-X

CASTAÑEDA, R. La reología en la caracterización y tipificación de quesos. Tecnología Láctea Latinoamericana, v. 26, p. 48-53, 2002.

DE VUYST, L. et al. Recent developments in the biosynthesis and applications of heteropolysaccharides from lactic acid bacteria. International Dairy Journal, v. 11, p. 687-707, 2001. http://dx.doi. org/10.1016/S0958-6946(01)00114-5

DUBOC, P.; MOLLET, B. Applications of exopolysaccharides in the dairy industry. International Dairy Journal, v. 11, p. 759-768, 2001. http://dx.doi.org/10.1016/S0958-6946(01)00119-4

FRAU, F. Desarrollo de quesos untables de cabra usando fermentos lácticos autóctonos, como estrategia tecnológica para la cuenca caprina de Santiago del Estero. 2011. Tese (Doutorado em Ciencia e Tecnologia de Alimentos: Modalidade Engenharia)-Facultad de Agronomía y Agroindustrias, Universidad Nacional de Santiago del Estero, Santiago del Estero, 2011.

GUINEE, T.; PUDJA, P.; FARKYE, N. Fresh Acid-Curd Cheese Varieties. In: FOX, P. F. (Ed.). Cheese: Chemistry, Physics and microbiology. Maryland, 1999. cap. 13, p.363-419.

HASSAN, A. N. J. Possibilities and Challenges of ExopolysaccharideProducing Lactic Cultures in Dairy Foods. Journal of Dairy Science, v. 91, p. 1282-1298, 2008. PMid:18349221. http://dx.doi. org/10.3168/jds.2007-0558

HASSAN, A. N. et al. Microstructure and rheology of an acid-coagulated cheese (Karish) made with an exopolysaccharide-producing Streptococcus thermophilus strain and its exopolysaccharide non- producing genetic variant. Journal of Dairy Research, v. 71, p. 116-120, 2004. PMid:15068074. http://dx.doi.org/10.1017/ S0022029903006605

HASSAN, A. N. et al. Microstructure and Rheology of Yogurt Made with Cultures Differing Only in Their Ability to Produce Exopolysaccharides. Journal of Dairy Science, v. 86, p. 1632-1638, 2003. http://dx.doi.org/10.3168/jds.S00220302(03)73748-5

HERNÁNDEZ-TINOCO, A. et al. Rheometry and scanning electron microscopy study of casein curds added with mequite seed gum and soy proteins. Latin American Applied Research, v. 42, p. 195-202, 2004.

JIMÉNEZ-GUZMÁN, J. et al. Use of an exopolysaccharide-producing strain of Streptococcus thermophilus in the manufacture of Mexican Panela cheese. LWT - Food Science and Technology, v. 42, p. 1508-1512, 2009.

KEALY, T. Application of liquid and solid rheological technologies to the textural characterisation of semi-solid foods. Food Research International, v. 39, p. 265-276, 2006. http://dx.doi.org/10.1016/j. foodres.2005.07.016

KELLY, A. L.; O’DONNELL, H. J. Composition, Gel Properties and Microstructure of Quarg as Affected by Processing Parameters and Milk Quality. International Dairy Journal, v. 8, p. 295-301, 1998. http://dx.doi.org/10.1016/S0958-6946(98)00084-3

LARIBI, S. et al. Comparative yield stress determination for pure and interstratified smectite clays. Rheologica Acta, v. 44, p. 262-269, 2005. http://dx.doi.org/10.1007/s00397-004-0406-3

LUCEY, J. A. et al. A comparison of the formation, rheological properties and microstructure of acid skim milk gels made with bacterial cultures or glucono-d-lactone. Food Research International, v. 31, p. 147-155, 1998.

LUCEY, J. A. et al. Properties of acid casein gels made by acidification with glucono-d-lactone. 2. Syneresis, permeability and microstructural properties. International Dairy Journal, v. 7, p. 389-397, 1997.

MESSENS, W. et al. Rheological properties of high-pressure-treated Gouda cheese. International Dairy Journal, v. 10, p. 359-367, 2002. http://dx.doi.org/10.1016/S0958-6946(00)00066-2

ROEFS, S. P. F. M.; DE GROOT-MOSTERT, A. E. A.; VAN VLIET, T. Structure of acid casein gels.1.formation and model of gel network. Colloids Surf, v. 50, p. 141-159, 1990. http://dx.doi. org/10.1016/0166-6622(90)80259-7

RUAS-MADIEDO, P.; HUGENHOLTZ, J.; ZOON, P. An overview of the functionality of exopolysaccharides produced by lactic acid bacteria. International Dairy Journal, v. 12, p. 163-171, 2002. http:// dx.doi.org/10.1016/S0958-6946(01)00160-1

SAN MARTÍN, M. et al. Yield, composition and rheological characteristics of cheddar cheese made with high pressure procesed milk. LWT - Food Science and Technology, v. 40, p. 697-705, 2007.

SÁNCHEZ MARTÍNEZ, J. Potencial biotecnológico de bacterias lácticas silvestres en productos lácteos fermentados: actividad metabólica y producción de exopolisacáridos. 2005. Tesis (Doctoral)-Instituto de Productos Lácteos de Asturias, Universidad de Oviedo, Villaviciosa, 2005.

SKRIVER, A. Chacterization of stirred yoghurt by rheology, microscopy and sensory analysis. 2011. Tesis (Doctoral)- Royal Veterinary and Agricultural University Denmark, Denmark, 1995. 
SOYDEMIR, E. Determination of whey based medium requirements and growth characteristics for the production of yoghurt starter cultures. 2008. Tesis (Master of science in Biotechnology and Bioengineering)-University of Pretoria, Pretoria, 2008.

VAN VLIET, T. Structure and rheology of gels formed by aggregated protein particles. In: NISHINARI, K. Hydrocolloids-Part 1. Physical Chemistry and Industrial Application of Gels, Polysaccharides, and Proteins. Amsterdam, 2000. p. 367-377.
WACHER-RODARTE, C. et al. Yogurt production from reconstituted skim milk powders using different polymer and non-polymer forming starter cultures. Journal of Dairy Research, v. 60, p. 247-254, 1993. http://dx.doi.org/10.1017/S0022029900027564

WELMAN, A. D.; MADDOX, I. S. Exopolysaccharides from lactic acid bacteria: perspectives and challenges. Trends Biotechnology, v. 21 , n. 6 , p. $269-274,2003$. http://dx.doi.org/10.1016/S01677799(03)00107-0 